\title{
Hand hygiene excellence award winner: spreading the experience countrywide in Romania
}

\author{
A Moldovan ${ }^{1 *}$, M Capilna ${ }^{2}$, I Cotoara', B Moldovan ${ }^{3}$ \\ From 3rd International Conference on Prevention and Infection Control (ICPIC 2015) \\ Geneva, Switzerland. 16-19 June 2015
}

\section{Background}

Hospital "Sf.Constantin » was designated among the winners of the "European Hand Hygiene Excellence Award » (2013). This award turned the winner medical team into a promoter of infection control, as part of the missions given to HHEA awardees.

\section{Objectives}

Improving hygiene in Romania.

\section{Methods}

The promotion of actions was conducted as: know-how in hospitals; organization of workshops/courses (infectious diseases, epidemiology, use of invasive devices, prevention of bloodstream infections, antibiotic stewardship); co-organization of two annual workshops with international participation; initiating the 5 May (WHO hand hygiene day) celebrations in Romania; translation into Romanian of books in the field.

\section{Results}

Since 2013, we conducted 29 courses/workshops in 16 towns. The number of participants was 1530 . The topics encompassed 17 themes. All presentations were made in the spirit of the economy of peace, i.e. pro-bono. We gave the materials, initiated on-line feed-back. We contributed to the completion of four master theses, and we are are doing the initiation of a patient's education program. Instructed professionals came from surgery (51\%), oncology (27\%), intensive care (16\%) and medicine (6\%), being registered nurses $(65 \%)$, doctors $(25 \%)$, other $(10 \%)$. We are involved in three major projects in regards to the implementation of infection control measures.

'Prevention and Control of Infections, Sf Constantin Hospital, Brasov, Romania

Full list of author information is available at the end of the article

\section{Conclusion}

As HHEA winner, our institution contributes to spread infection control/hospital epidemiology in Romania. Our experience verifies the idea of considering hand hygiene as the entrance door to infection control.

\section{Disclosure of interest}

None declared.

\section{Authors' details}

${ }^{1}$ Prevention and Control of Infections, Sf Constantin Hospital, Brasov, Romania. ${ }^{2}$ Obstetrics\& Gynecology, Sf Constantin Hospital, Brasov, Romania. ${ }^{3}$ General Surgery, Sf Constantin Hospital, Brasov, Romania.

Published: 16 June 2015

doi:10.1186/2047-2994-4-S1-P148

Cite this article as: Moldovan et al:: Hand hygiene excellence award winner: spreading the experience countrywide in Romania. Antimicrobial Resistance and Infection Control 2015 4(Suppl 1):P148.

\section{Submit your next manuscript to BioMed Central and take full advantage of: \\ - Convenient online submission \\ - Thorough peer review \\ - No space constraints or color figure charges \\ - Immediate publication on acceptance \\ - Inclusion in PubMed, CAS, Scopus and Google Scholar \\ - Research which is freely available for redistribution

